\title{
The Intra-venous Chlorpropamide Response Test in Diabetes Mellitus
}

\author{
K. YAMADA, Y. SHIBATA, S. ITO, N. SAKAMOTO, \\ T. KOIDE, K. AOYAMA, A. NIKI, N. KATUMATA, \\ I. TSUTIDA, N. NONOGAKI, T. KUNO and K. ABE
}

The 3rd Department of Internal Medicine, School of Medicine, Nagoya University

The standard oral glucose tolerance test has been used for many years for the diagnosis of diabetes mellitus. In 1957, the intravenous tolubutamide response test and then the intravenous chlorpropamide response test were introduced as a complement to, or a replacement of, the glucose loading test. These are the test using the hypoglycemic action provoked by sulfonylureas for diagnostic purposes. In the present report we analyze the conclusion arising from the study of the glycemic curves obtained by the intravenous use of chlorpropamide. This test was done in 30 diabetic subjects and 5 normal subjects. After an overnight fasting, chlorpropamide was administered intravenously in dosis of $500 \mathrm{mg}$ dissolved in $5.2 \mathrm{ml}$ of physiologocal saline solution over a period of 2 minutes. Blood specimens were obtained before injection and at 20,30, 40, and 60 minutes after the middle of the injection period. Bood sugar levels were determined by the method of Hagedorn-Jensen. The normal subjects showed glycemic curves with the following average percentage decrease with respect to initial values: after 20 minutes $25.4 \%$, after 30 minutes $39.2 \%$, after 40 minutes $21.4 \%$, and after 60 minutes $10.4 \%$.

The diabetic subjects showed glycemic curves with the following average percentage decrease: after 20 minutes $4.3 \%$, after 30 minutes $7.9 \%$, after 40 minutes $10.6 \%$ and after 60 minutes $12.7 \%$. There are separation at the level of $30 \%$ in glycemic decrease at 30 minutes and $20 \%$ at 20 minutes, and the values for the control subjects are above it and the values for the diabetics below it.

Between the chlorpropamide response curves of "control type" and "diabetic type", there seems to be a net difference at 30 minutes. But from a discriminative viewpoint, in addition to the value at 30 minutes, it would be safer to concider the value after 20 minutes. These curves are a certain similarity between glycemic curve of response to insulin and glycemic curve that provoked by tolbutamide. None of the cases showed signs of reactions caused by hypoglycemia and other remarkable side effects. In the result, the intravenous chlorprpamide response test appears to have quality as a new diagnostic procedure for diabetecs mellitus, especially for mild diabetes.

(pp. 489 499) 


\section{糖尿病者に於ける Chlorpropamide 静注試験（Diabinese-Test） に対する考察}

名古屋大学医学部山田内科

山田 弘三, 柴田 昌雄, 伊藤 清次, 坂本 信夫

小出 忠孝, 青山 克己，仁木 厚，勝又 一夫

土田勇, 野々垣尚彦, 久野勉, 阿部 和世

(昭和38年 5 月 21 日受附)

\section{諸言}

糖尿病の診断には現在では通常耐糖力試験（葡萄糖経口負荷試験，同静注試験，飽食試験）によつて行な われている. 之らの方法は試験結果に変化を与える食餌, 運動及び胃晹吸収の椂な外部的要素がある為に最 善の場合でも完全に満足すべきものではない，或いは又高令者，肝疾患を有するものでは耐糖力低下を示す 場合があり，又糖尿病域と正常域の中間に位する場合には耐糖力試験と別の基礎による診断法の必要にせま られてくる。乙の様な時に Mirsky et al') は1956年に糖尿病者と非糖尿病者とでは経口投与した Na-Tolbutamide 亿対する低血糖反応が著しく異なる事を報告した. 更に Unger et $\mathrm{al}^{2}{ }^{2}$ は軽症糖尿病と非糖尿病者と で静注投与された Na-Tolbutamide 亿対する反応に相違がある事より, 軽症糖尿病の診断規準を発表した 結果 Tolbutamide 静注試験は糖尿病の新しい診断法として注目されるに至つた。一方 Tolbutamide と同 様の作用機序を有する Chlorpropamide 亿関しては Brigante et a ${ }^{33}$ の Chlorpopamide 静注試験に関する 研究があり，糖尿病と非糖尿病との間に明らかな差を認めている。

私共は今回正常人及び糖尿病者に対して Chlorpropamide 静注試験 (Diabinese Test一静注用 Diabinese は台糖ファイザー社提供）を施行し，その成績を検討する機会をえたので，その成績を発表する。

\section{被験者及び試験法}

当内科糖尿病外来受豂中及び入院中の糖尿病患者 30 例及び非糖尿病者 5 例，計 35 例を被験者とした，糖尿 病者30例中男14例，女16例で，年令は20〜66才に及んでいる。体型別では肥満型 9 . 正常型15. るいそう型 6 であり, 罹病年数別では 1 年未満 $7.1 \sim 4$ 年 $9.5 \sim 9$ 年 9.10 年以上 5 例であり, 又合併症を有する もの19. 無いもの11例である. 病状については空腹時血糖值 $200 \mathrm{mg} / \mathrm{dl}$ 以上 6 例. $200 \sim 120 \mathrm{mg} / \mathrm{dl} 8$ 例. 120 $\mathrm{mg} / \mathrm{dl}$ 以下 16 例（ての中に $100 \mathrm{mg} / \mathrm{dl}$ 以下のもの11例を含む）であり, 又既往の治療法についてはInsulin と 経口剤の併用 19 例. 経口鼡治療 6 例. 未治療 5 例の分類となる. 之らの症例に対し早朝空腹時, 静注用 chlorpropamide（以下P 607 と略す） $500 \mathrm{mg}$ t生理的食塩水 $5.2 \mathrm{cc}$ 中に溶解し，約 2 分間かけて静注. 注射 前及び注射後 $20 ， 30 ４ 0$ 及び60分後に採血，Hargedorn-Jensen 氏法にて血糖値を測定した。

\section{成 績}

I ) 正常者 (Table 1, Fig. 1, 2, 4 (a))

正常者に P $607500 \mathrm{mg}$ 静注後の血糖曲線は Insulin 静注後の反応曲線と似た急激な血糖低下を示した後恢 復に向つた. 血糖值の最大下降率は静注後30分でおき，その平均血糖下降率は $39.2 \% て ゙ 36 〜 43 \% の$ 範囲内で あつた. 20 分值の平均下降率は $25.4 \% て ゙ 21 〜 32 \% の$ 範囲内であり，40分值の平均下降率は $21.4 \%$ で16〜27\%

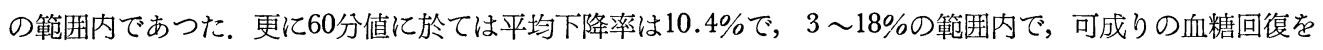
示している. 従つて P 607静注後の正常な反応は 30 分で急激な血糖の減少を特徵とし, 又 60 分後に可成りの 程度の血糖回復反応を示す事を特徵とするという事ができる. 
Table 1. The intravenous chlorpropamide response test in normals

\begin{tabular}{|c|c|c|c|c|c|c|c|c|c|c|c|c|c|c|c|c|c|}
\hline \multirow{3}{*}{ No. } & \multirow{3}{*}{ Name } & \multirow{3}{*}{ Age } & \multirow{3}{*}{ Sex } & \multirow{3}{*}{ Type } & \multicolumn{9}{|c|}{ Intravenous chlorpropamide Test } & \multirow{3}{*}{$\begin{array}{l}\max . \\
\text { decrease } \\
(\%)\end{array}$} & \multirow{3}{*}{\begin{tabular}{|} 
Time to \\
reach \\
the \\
nadir \\
(min.)
\end{tabular}} & \multirow{3}{*}{$\begin{array}{l}\text { Sensiti- } \\
\text { vity } \\
\text { index }\end{array}$} & \multirow{3}{*}{$\begin{array}{l}\text { Side } \\
\text { effect }\end{array}$} \\
\hline & & & & & \multicolumn{5}{|c|}{ Blood $\underset{(\mathrm{mg} / \mathrm{dl})}{\text { Sugar level }}$} & \multicolumn{4}{|c|}{$\begin{array}{l}\text { Blood Sugar } \\
\text { decrease }(\%)\end{array}$} & & & & \\
\hline & & & & & 0 & 20 & 30 & 40 & 60 分 & 20 & 30 & 40 & 60 分 & & & & \\
\hline 1 & A.M. & 36 & 今 & $\mathrm{n}$ & 82 & 55 & 48 & 64 & 67 & 23 & 42 & 22 & 18 & 42 & 30 & 1.40 & $(-)$ \\
\hline 2 & S.A. & 23 & 우 & $\mathrm{n}$ & 89 & 63 & 56 & 63 & 81 & 29 & 36 & 21 & 9 & 36 & 30 & 1.20 & $(-)$ \\
\hline 3 & H. Y. & 45 & 우 & $\mathrm{n}$ & 90 & 71 & 58 & 71 & 87 & 21 & 36 & 21 & 3 & 36 & 30 & 1.20 & $(-)$ \\
\hline 4 & K.M. & 18 & 우 & $\mathrm{n}$ & 93 & 63 & 53 & 68 & 82 & 32 & 43 & 27 & 12 & 43 & 30 & 1.43 & $(-)$ \\
\hline 5 & K. S & 40 & 令 & $\mathrm{n}$ & 81 & 63 & 50 & 68 & 73 & 22 & 39 & 16 & 10 & 39 & 30 & 1.30 & $(-)$ \\
\hline \multicolumn{5}{|c|}{ Mean } & 87 & 63 & 53 & 67 & 79 & 25.4 & 39.2 & 21.4 & 10.4 & 39.2 & 30 & 1.31 & $(-)$ \\
\hline
\end{tabular}

$\mathrm{n}$ : normal type

Fig. 1. Mean chlorpropamid response curves in normals and diabetics

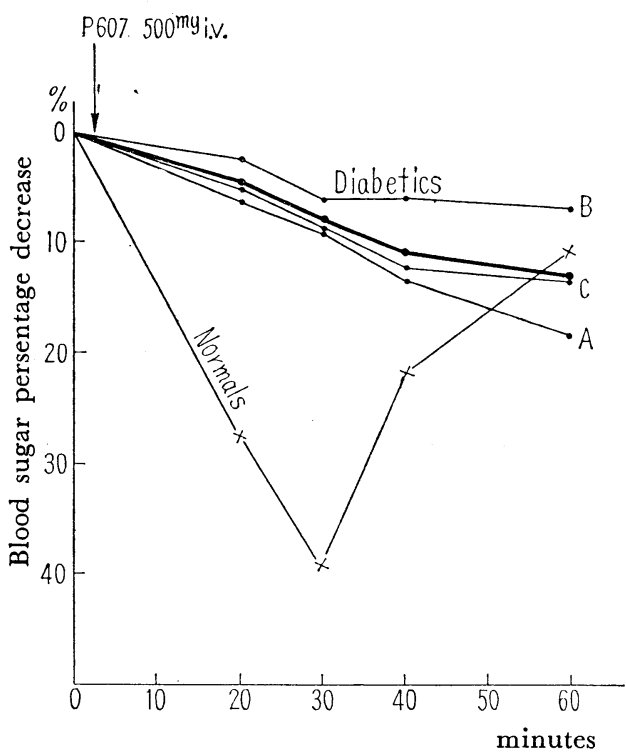

Mean curve of :

5 Normals $x \longrightarrow x$

30 Diabetics $\cdot$

$\left\{\begin{array}{l}\text { A }: 6 \text { diabetics with } \mathrm{FBS}>200 \mathrm{mg} / \mathrm{dl} \\ \text { B }: 8 \text { diabetes withFBS } 200 \sim 140 \mathrm{mg} / \mathrm{dl} \\ \text { C }: 16 \text { diabetics with } \mathrm{FBS}<140 \mathrm{mg} / \mathrm{dl}\end{array}\right.$
Fig. 2. Data on the chlorpropramide response tests of 5 normals and 30 diabetics

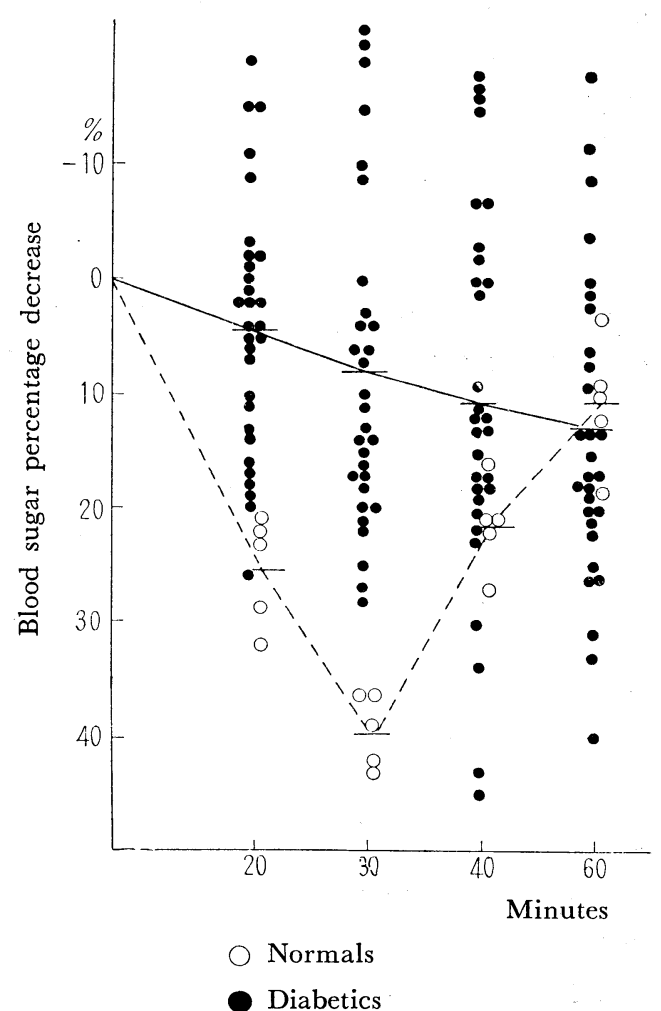




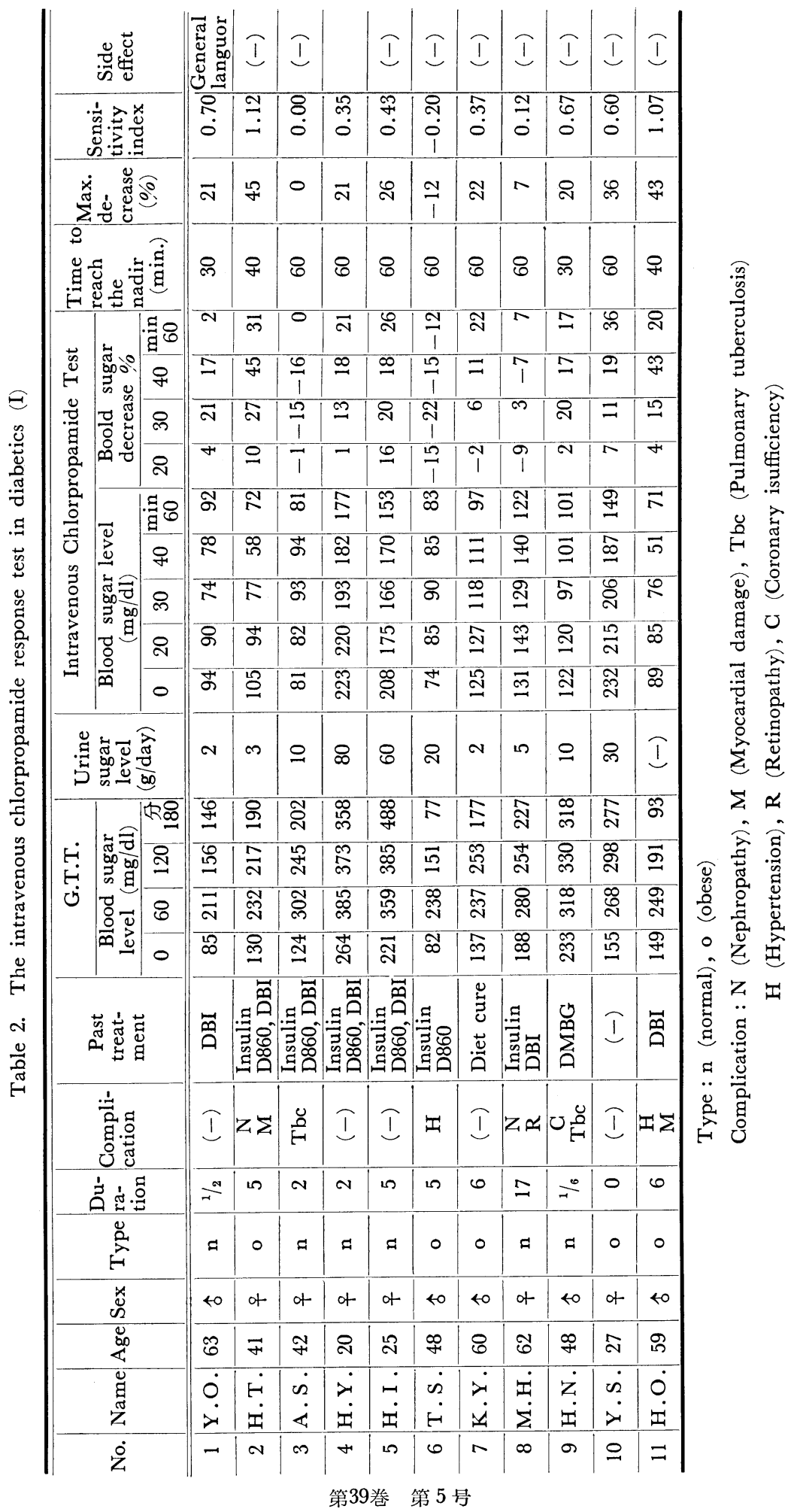




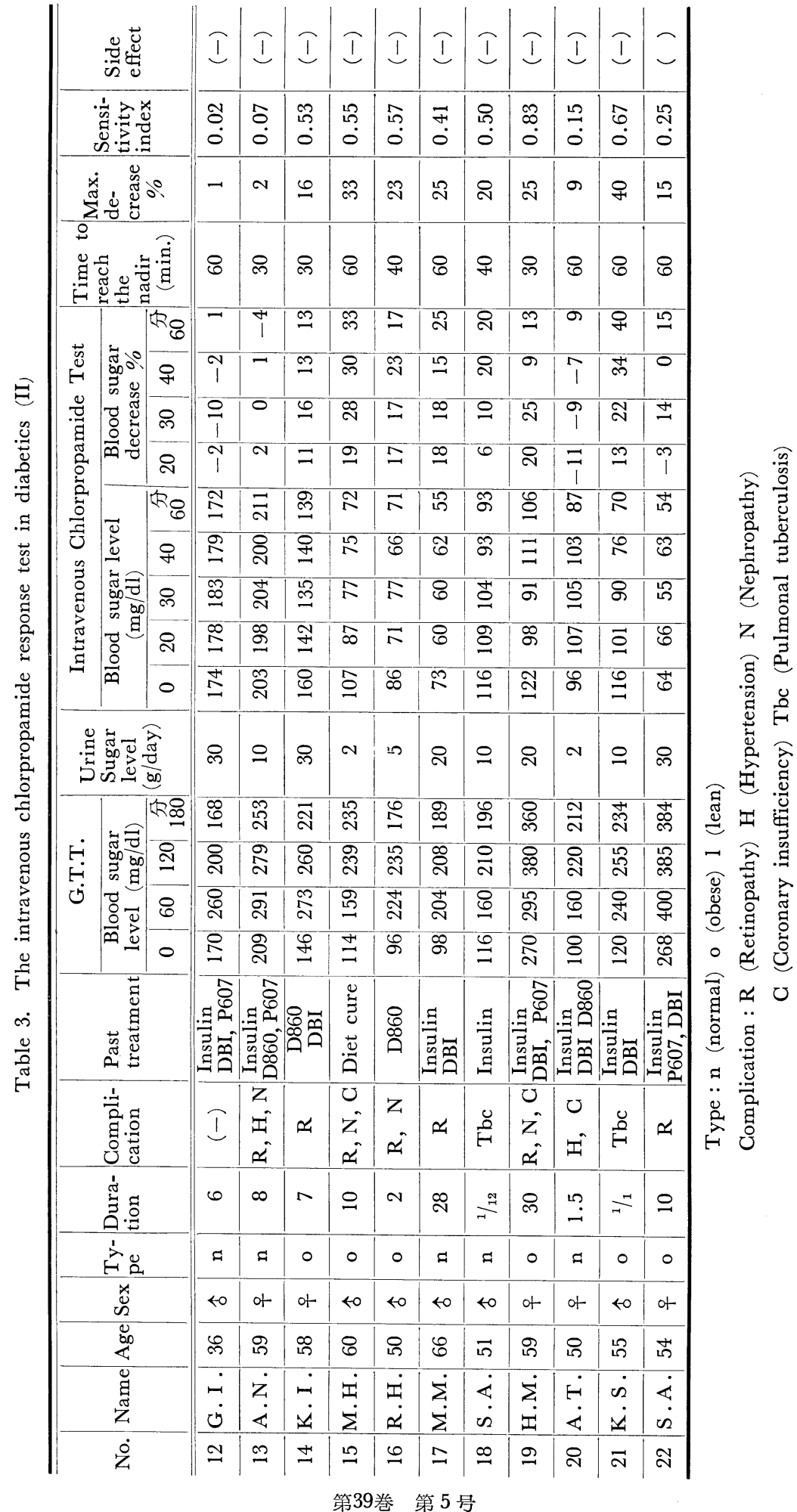




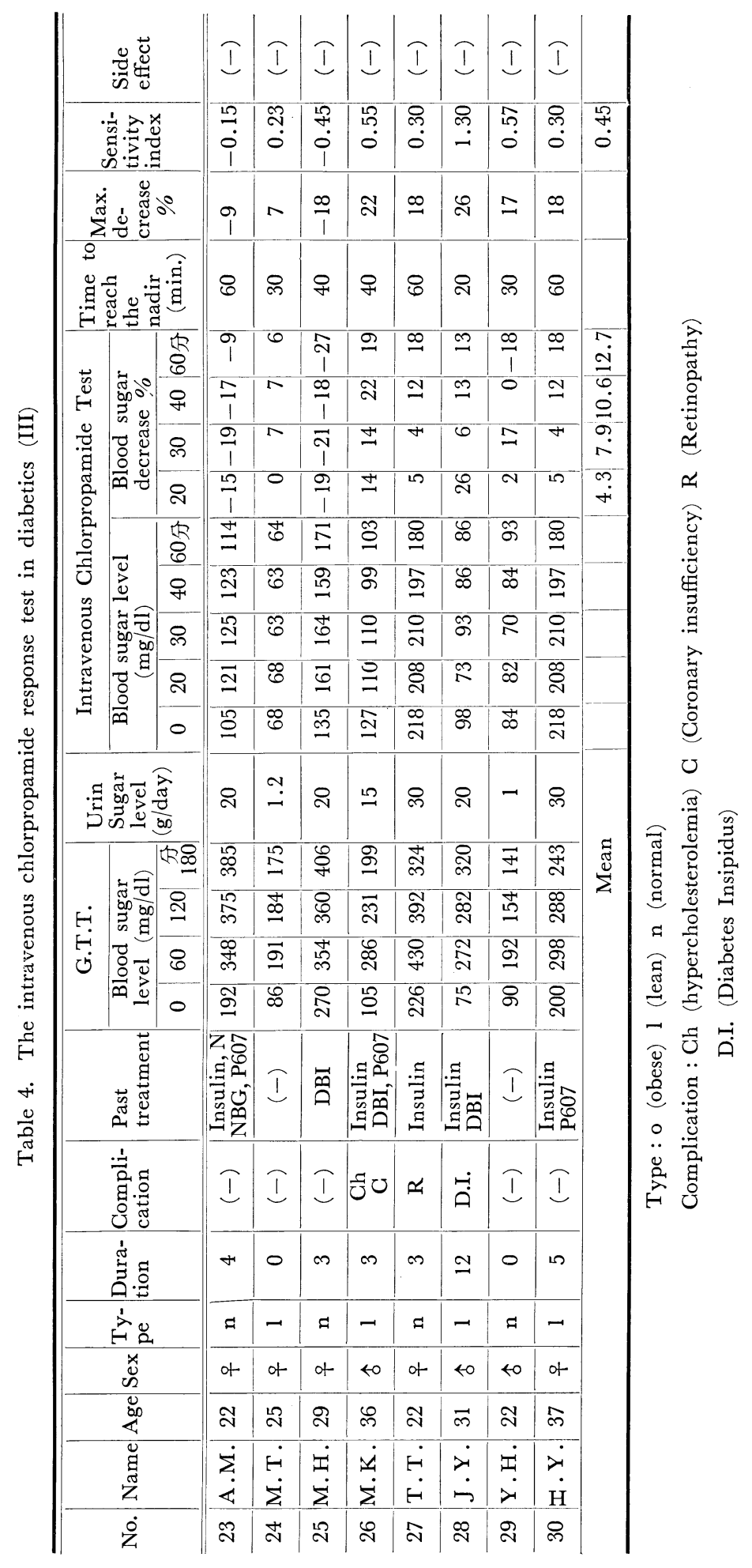


II) 糖尿病者 (Table 2, 3, 4. Fig. 1, 2, 4 (b))

P 607 静注後の血糖曲線は正常者と明らかに異なり血糖の低下が緩徐であり，又血糖回復反応もみられな いか或は軽度である. 特に P 607 静注後血糖の上昇を示すものをみる事も又特異的である. 血糖の最低值に 達する所要時間は静注 20 分後が 1 例. 30 分が 7 例. 40 分が 6 例であり, 最も多いのは60分後迄血糖が下降し て回復を示さない16例 $(53.3 \%)$ である.

20分値に於ける平均血糖下降率は $4.3 \%$ で，その範囲は $19 \%$ の昇から $26 \%$ 低下迄であり，30分值の平 均血糖下降率は $7.9 \%$ でその範囲は $22 \%$ の上昇より $28 \%$ の低下迄であり，40分值の平均血糖下降率は $10.6 \%$ で，その範囲は18\%の上昇より $45 \%$ の低下であり, 更に60分值の平均下降率は $12.7 \%$ でその範囲は $27 \%$ 上 昇より $40 \%$ の低下迄であつた。 即ち 30 例の糖尿病の平均下降率に於ては60分後迄緩徐な血糖低下を示してい る. 30分值の血糖下降率では全例28\%以内の低下で正常人の36\%以上の低下と明らかに区別しうるに対して, 20分值の下降率では 1 例のみが正常域により，他の 29 例は $30 \%$ を境界として正常人と区別し得る. 之に対し て40分值では 6 例 $(20 \%)$ が正常人の平均下降率より低く, 又60分值では19例 $(63.3 \%)$ が正常の平均下降 率より低くなる．従つてての場合は正常人と糖尿病者との重複がみられる．従つて P 607 静注後の糖尿病群 の血糖反応の特徵は, 血糖低下が徐々におこり73\%が40分以後に最大に達し著しい血糖回復反応を示さない 事である.

次に血糖下降率と症状との関係（Fig. 1，Fig. 3 (c)）についてみると，空腹時血糖值により $200 \mathrm{mg} / \mathrm{dl}$ 以

Fig. 3. Blood sugar percentage decrease at 30 minutes after chlorpropamide intravedous injection in diabetics

a) Relation to Age

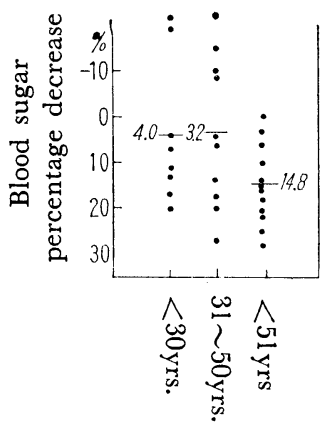

b) Relation to Type

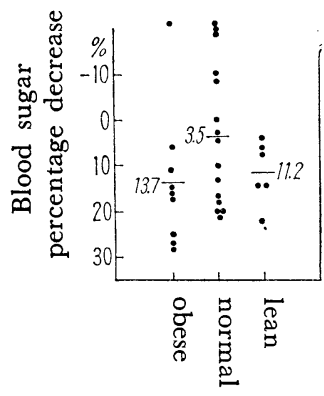

c) Relation to Fasting Blood Sugar

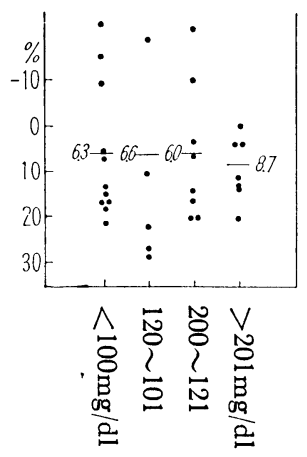

d) Relation to Duration

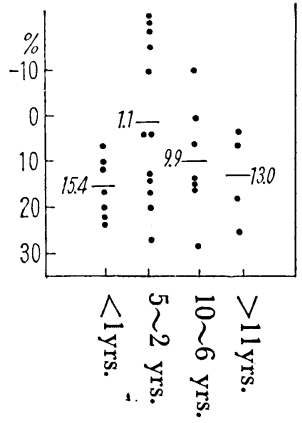

e) Relation to Complication

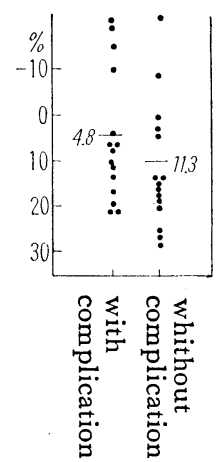

f) Relation to Insulin Treatment
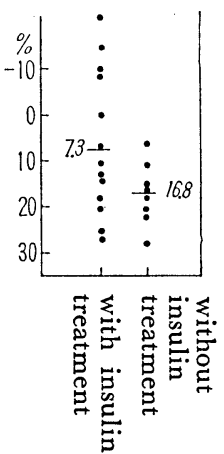
Fig. 4. The intravenous chlorpropamide response test in normals and diabetics

a) Normals

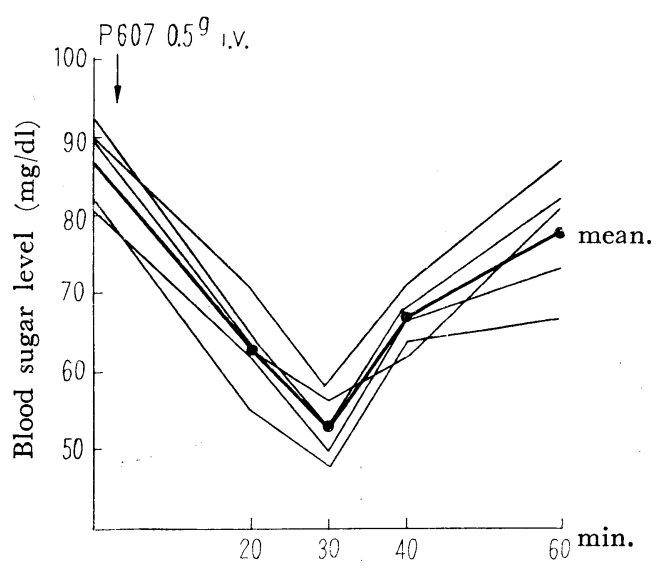

上, $200 \sim 120 \mathrm{mg} / \mathrm{dl}, 120 \mathrm{mg} / \mathrm{dl}$ 以下の三段階に分 類し各群の血糖下降率曲線を比較するに，3群とも 緩徐な血糖の低下と，回復反応を示さないという特 徵を示し, 各群の血糖降下率の間には大きな差異を 認めない. 30分值の下降率の病状別の分布をみても 各群の間に著明な差がみられない.

年令との関係（Fig. 3 (a)）では30才以下，30～50 才，50才以上の若年性, 壮年性, 向老性の 3 群に分 つと, 若年性, 壮年性の間には有意の差を認めない が向老性の群では血糖低下が大であり, 前の 2 群と 著明な差を認める。

体型との関係（Fig. 3 (b)）では標準体重の+10\% 以上， $-10 \%$ 以下の肥満型，るいそう型の間に有意 の差を認めず，正常型のみが之ら 2 群と異なり血糖 下降率が小である.

羅病年数との関係では（Fig. 3 (d)） 1 年以内， 2 〜 年, $6 \sim 10$ 年, 11 年以上の 4 群に分つと $1 \sim 5$ 年群は血糖低下が小であるが，その他の群では有意 の差を認めない。

合併症との関係では（Fig. 3 (e)）糖尿病性網膜症， 婜症，心疾患及び高血圧症等血管系の合併症を有す る群は，合併症のない群より血糖低下が小である。 又既往の Insulin 注射の有無との関係では（Fig. 3 (f)) Insulin 治療歴を有する群に血糖下降率が少で ある。

又感性指数 $\left(=\frac{\text { 最大血糖下降率 }(\%)}{\text { 最低值に達する所要時間 }(\text { 分 })}\right)$ b) Diabetics

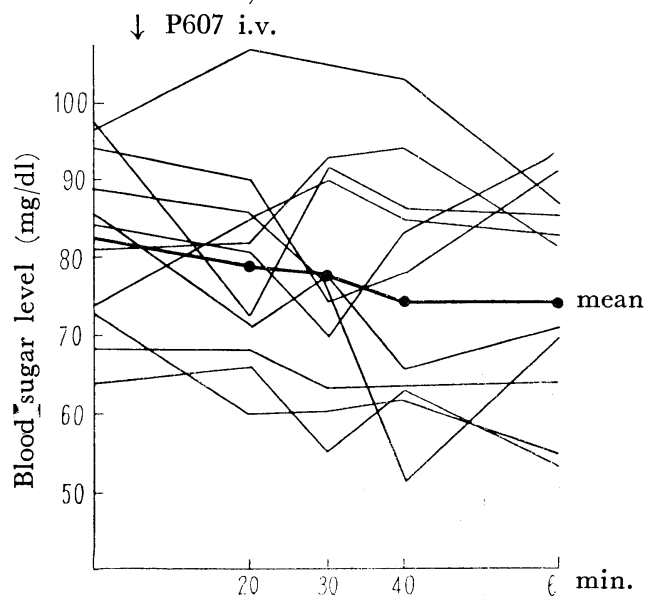

Fig. 5. Ghlorpropamide sensitivity index in normals and diabetics

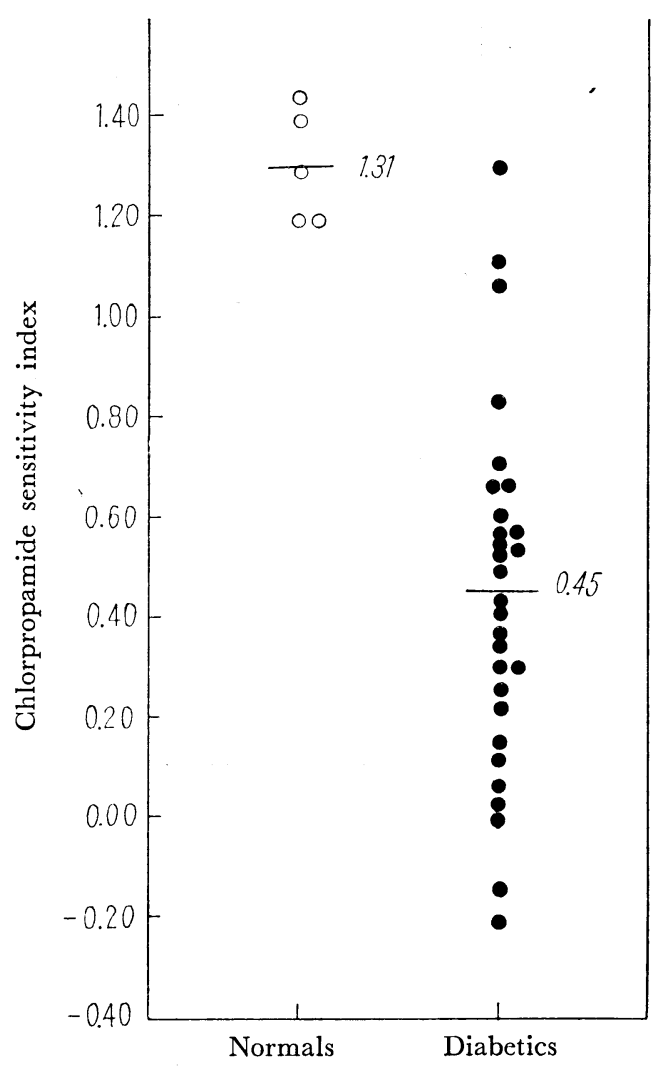




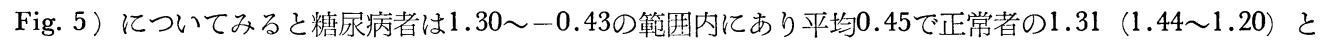
著明な差を認める. 之と病状との関係では軽症 0.48 , 中等症 0.46 , 重症 0.34 で重症に於て感性指数の低下を 認める。

III) 軽症糖尿病者と正常者との比較 (Fig. 4, Table 5)

空腹時血糖值 $100 \mathrm{mg} / \mathrm{d}$ 以下の正常值を有するが，GTTに於て糖尿病と診断される11例と，正常者とを比 較すると, 空腹時血糖值が大体同じ範囲内にあるにも拘らず，P 607 静注後の血糖曲線は著明な差を有し， 糖尿病群では極めて緩徐な血糖低下を来すにすぎない．血糖下降率についてみると正常者の 20 分值 $25.4 \%$,

Fig. 6. Comparison with the intravenous chlorpropamide response test and the intravenous tolbutamide response test

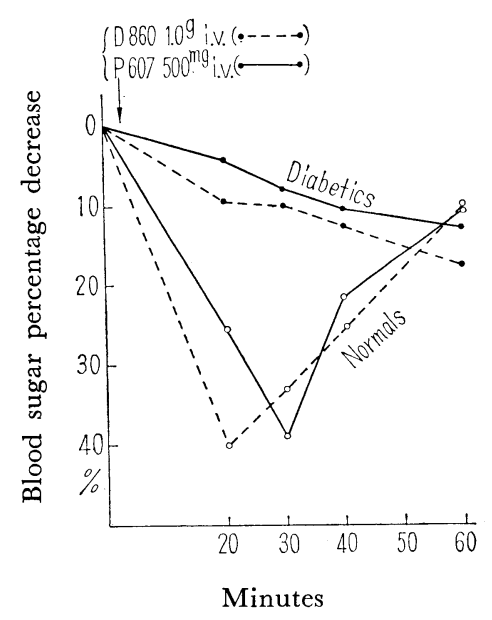

Case 1

Case 2

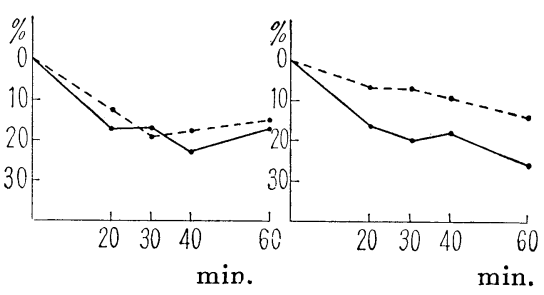

Case 3

Case 4

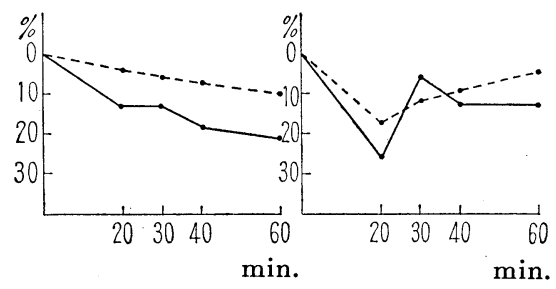

Table 5. The mean blood sugar percentage decrease after intravenous chlorpropamide injection in normals and diabetics

\begin{tabular}{|c|c|c|c|c|c|c|c|c|}
\hline & & \multirow{2}{*}{$\begin{array}{l}\text { No. } \\
\text { of Case }\end{array}$} & \multirow{2}{*}{$\begin{array}{l}\text { Fasting } \\
\text { blood } \\
\text { sugar }\end{array}$} & \multicolumn{4}{|c|}{$\begin{array}{l}\text { Intravenous chlorpropamide } \\
\text { test : Blood sugar decrease \% }\end{array}$} & \multirow{2}{*}{$\begin{array}{l}\text { Sensitivity } \\
\text { index }\end{array}$} \\
\hline & & & & 20 & 30 & 40 & $60 \mathrm{~min}$. & \\
\hline & Normals & 5 & $87 \mathrm{mg} / \mathrm{dl}$ & 25.4 & 39.2 & 21.4 & 10.4 & 1.31 \\
\hline \multirow{5}{*}{ 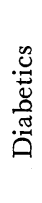 } & Fasting blood sugar & & & & & & & \\
\hline & $>200 \mathrm{mg} / \mathrm{dl}$ & 6 & 217 & 6.0 & 8.7 & 13.3 & 19.5 & 0.34 \\
\hline & $200 \sim 120 \mathrm{mg} / \mathrm{dl}$ & 8 & 162 & 2.5 & 6.0 & 5.6 & 6.9 & 0.46 \\
\hline & $<120 \mathrm{mg} / \mathrm{dl}$ & 16 & 91 & 4.6 & 8.6 & 12.0 & 13.0 & 0.48 \\
\hline & $(<100 \mathrm{mg} / \mathrm{dl})$ & (11) & (83) & $(3.7)$ & $(6.3)$ & $(7.3)$ & $(7.0)$ & $(0.46)$ \\
\hline & Mean & 30 & 146 & 4.3 & 7.9 & 10.6 & 12.7 & 0.45 \\
\hline
\end{tabular}

Table 6. The mean blood sugar percentage decrease after intravenous tolbutamide injection in normals and diabetics

\begin{tabular}{c|c|c|c|c|c|c|c}
\hline Normals & 6 & $88 \mathrm{mg} / \mathrm{dl}$ & $40.3 \%$ & $33.0 \%$ & $/$ & $10.0 \%$ & 2.01 \\
\hline Diabetics & 21 & 150 & 9.4 & 9.9 & $/$ & 17.7 & 0.43 \\
\hline
\end{tabular}


30 分值 $39.2 \%$ に比し，軽症糖尿病者は 20 分值 $3.7 \%$. 30分值 $6.3 \%$ と明瞭な差を認める. 又感性指数を求めて も正常者の 1.31 に比し 0.46 と明らかに小であり, 正常者との鑑別診断に本試験が有効である事を示してい る.

IV) D860静注試験とP607静注試験との比較（Fig. 6，Talle 5，6)

D860静注試験を正常者 6 例. 糖尿病者21例に行ない，P607試験の成績とを比較すると，正常者では最低 值に達する時間がD860の20分に比しP607では30分と少し遅延するが最大下降率は $40.3 \% ， 39.2 \%$ とぼ同 様であり, 又60分後の血糖回復も $10 \%, 10.4 \%$ と同值を示し, 血糖の急激な低下と 60 分後の血糖の回復とい う同じ型の反応曲線を示す。一方糖尿病に於いては20分，30分，60分值が P 607 の.3\%，7.9\%，12.7\%に 対し，D860は9.4\%，9.9\%，17.7\% とやや低下の率が大であるが静注後 60分迄血糖の緩徐な低下という同 ビ反応曲線を示す.

同一症例に行なつたD860，P607静注試験の比較に於ても，多少画者の間で差を認めるが，大体に於て同 じ傾向の反応曲線を示している。

\section{V) 副作用}

正常者に於て P 607 静注後, 全身僚急感 3 例を認めたが低血糖症状はみられず，他の 2 例は全く異常はな かつた，糖尿病者では静注後血管痛を 2 例訴えた他に，全身倦急感を 1 例認めたのみで，それ以外に全く副 作用は認められなかつた。

\section{考按}

P607静注後の血糖曲線については J.G. Brigante etc $\left.{ }^{3}\right)$ の報告がある. 彼は既知の糖尿病遺伝のない正常 血糖值を有するもの15名（空腹時平均血糖伹 $86 \mathrm{mg} / \mathrm{dl}$ ) にP $607500 \mathrm{mg}$ 静注後，血糖曲線は20分で25.7\%， 30分で31.7\%，40分で30.2\%，60分で16.8\%の平均血糖下降率を示し，静注後の急激な血糖低下，30分後よ り血糖の回復するのを認めた. 之に対し GTT によつて診断された糖尿病20名（空腹時平均血糖值 $175 \mathrm{mg} /$ dl) の血糖曲線は，一般に正常と明らかに異なり，平均下降率に於て 20 分で5.8\%，30 分で 8.6\%, 40 分で $10.0 \%, 60$ 分で $12.6 \%$ と血糖低下が極めて少ない. 症例の $95 \%$ を含む統計的分類は, その各々のベルトに各 曲線を含み，之らのベルトを比較すると，20，40，60分の所で部分的に重複しているが，30分值に於て18\% の血糖下降率の処で分離されており，正常者は $18 \%$ 以上，糖尿病は18\%以下の血糖低下を示す事を認め，糖 尿病の判定規準に30分值18\%の下降率を提唱している. 又40分值については $20 \%$ 以の下降率の場合正常, $12 \%$ 以下の場合は糖尿病，12２0\%の時は糖尿病の疑いとし反復して検查を要すると判定規準を設けている. 更に又彼等は糖尿病遺伝のある正常血糖值を示す 27 名に対し本試験を施行し, 糖尿病型曲線が高い比率を占 める事を認め, 之が Conn etc $\left.{ }^{4}\right)$ CGTT の成績とよく一致する事より，本 Test が糖尿病の診断のみな らず，潜在性糖尿病或いは糖尿病前症の診断にも有意義である事を強調している.

一方 P607 と同じ作用機序を有する D860 の静注試験に関しては Unger ${ }^{2}$ ), Yallow ${ }^{5)}$, West ${ }^{6)}$, Fajans $^{7}$, Kaplan $^{8}$, , 桜井 ${ }^{9}$ etc の報告をみる. Ungar の成績によると, D860 1.0g 静注後 100 例の非糖尿病者に於て は20分後で40\%，30分後で $77 \% ， 60$ 分後で $28 \%$ 血糖低下を示すに対し，75例の軽症糖尿病群（空腹時血糖 $115 \mathrm{mg} / \mathrm{d} 1$ 以下が45例）に於ては20分 $10 \%, 30$ 分 $17 \%$ ，60分 $23 \%$ と徐々に血糖が低下するにすぎない事を認め た. そして20分值に於て $16 \%$ 以下の血糖減少を糖尿病域, $20 \%$ 以上を正常域とした場合, 被験者の $95 \%$ 於 てその判定が適中し，又30分值については $23 \%$ 以下を糖尿病域とすると，99\%に判定が適中する事を認め， D860静注試験が軽症糖尿病の鑑別診断に極めて有効である事を報告している.

私共のP 607静注試験の成績をみると平均血糖下降率に於て正常人では 30分後に $39.2 \%$ 血糖低下を示し て最低となり, 以後 60 分值に $10.4 \%$ 減少に迄回復する事及び糖尿病者では静注後血糖が徐々に下降し60分 後に12.7\%を示す血糖曲線を示す事は何れも Brigante の成績と全く一致している. しかしながら糖尿病の 判定規準についてみると，Brigante は30分值に於て18\%を境界として正常群と完全に分離している事より 18\%を判定規準に提唱しているが，之の規準に従うと正常者は $100 \%$ 正常域に属するが，糖尿病では7 例 
(23.3\%) が正常と判定される. 又 40 分值に於て $20 \%$ 以上を正常，12\%以下を糖尿病とする判定規隼に従う と，正常者の $80 \%$ は正常と診断され，20\%が糖尿病の疑いとなる. 又糖尿病者では $50 \%$ が糖尿病， 8 例 $(26$ .7\%) がその疑， 7 例 (23.3\%) が正常と判定される. 私共の成績から考光ると先ず20分値に於ては $20 \%$ 以 下を糖尿病とすると糖尿病の 29 例 $(96.7 \%)$ 亿判定が適中し，21\%以上を正常とすると正常者の $100 \%$ 亿判 定が適中する，又 30 分值に於ては $30 \%$ 以下を糖尿病，35\%以上を正常とすると両者とも $100 \%$ に診断が適中 する．そして 20 分值に於て $20 \%$ 以上の血糖下降率を示した糖尿病の 1 例も 30 分值に於ては $30 \%$ 以内であり糖 尿病と診断され得る４0分，60分值については，糖尿病者と正常者とが重複して分離し得ず鑑別点を決める 事が出来ない，以上より私共は30分血糖下降率江於て “30\%以下を糖尿病，35\%以上を正常，30～35\%は糖 尿病の疑いとして反復検査を必要とする゙という判定規準が適当であると考える. 又診断の補助としで20分 值に於て $20 \%$ 以下は糖尿病，21\%以上を正常とする”という判定規準を併用するは一圆診断を適確にすると 思われる，乙の規準に従うと GTT と本 test の成績は完全に一致する。

次に病状と P607 test との関係をみると正常者と糖尿病者とは明らかに区別し得るが，糖尿病者間では病 状の軽重と一定の関係がなく，略々同率の血糖下降曲線を示す。との事は30分の血糖下降率と病状との関係 に於てもみられる。かかる点より血糖下降率より糖尿病の病状を判定する事は不適当である。しかしながら 軽症の糖尿病に於ても正常と明らか飞異なる血糖曲線を画く事より，正常者と鑑別困難な軽症糖尿病の診断 に本 test が極めて有効である事が理解される。乙の様に軽症糖尿病の診断に本 test が有効である事は， 本 test の最大の長所である.

次に30分の血糖下降率と年令との関係では 30 孜以下の若年性が，50才以上の向老性患者に比して下降率が 小で，P607が向老性に有效である事と一致している，又血管合㳕症或いはInsulin 治療歴を有する症例に 下降率が小である事もP 607 の作用機序より考えて当然の事であるが，体型或いは罹病年数との間には一定 の関係がみられない事より本 test が個体のP 607亿対する感性を最も適切に表わしているとはいえない.

一方P 607 と同じ作用機序の D860の静注試験との比較については Brigante は，Ungar の D860静注試験 の成績と比較して正常人に於てはD860の方が血糖の下降が著しいと述べている．私共の成績によるとD860 に於ては最低値に達する時間が20分であるのに対し P 607 では30分とやや遅れるが最大下降率及び60分後の 血糖の回復は全く一致しており，本質的に同じ曲線を示すものと考元る，又糖尿病者に於ても静注後両者之 も徐々に血糖が低下し大体同様の血糖下降率を示す．乙の事は個々の同一症例に両 test 施行後の血糖曲線 に於てもみられ，P607とD860が同じ作用機序を有している事を実証している.

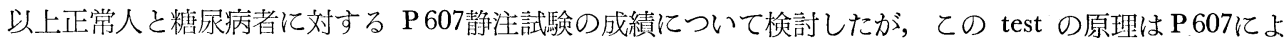
り菻より Insulin の放出が促され，従つて血糖が低下すると考光られている。それ故に十分な Insulin自己 生産によつて代償しうる非糖尿病性の糖同化能障害と島 $\beta$ 細胞分泌機序に障害のある潜在性或いは軽症糖尿 病とを鑑別する事が出来るのを特異的とされている。しかしててに於て P 607 にる低血糖の作用機序につ いて考えてみると $\mathrm{P}$ 607が作用を営むには $\beta$ 細胞の健在が前提条件である事が一般に認められているが，低 血糖が肝の glucose 放出の減少の結果であるか，或いは同時に又独立に末梢に於ける糖利用の增大による

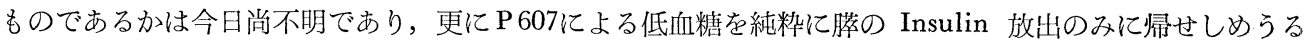
かは今日尚疑わしい．しかしながら作用機序の問題は別としてP 607 静注後の 血糖低下に正常者と糖尿病者 との間に明らかな差のある事も私共の成績より確かである。この点より本 test が正常人と糖尿病者との鑑 別に極めて有力であると考光られる. 更に本 test が30分間 3 回の採血で終了しうる事は医師及び患者にと つて目担が少なく，又検査法として臨床的に安全で容易に実行できる事もての test の長所の一つであろう， 以上より本 test は糖尿病の診断に対して充分な感度と特翼性をもつており，ての目的の為に今日一般に用 いられている他の検查法に十分匹敵するものであると考光る。

\section{結 論}

1）糖尿病 30 名, 正常人 5 名に対して P 607静注試験を行ない，その血糖曲線について検討を行なつた。 
2）正常者に於ては血糖下降率が20分後 $20 \%$ 以上，30分後 $35 \%$ 以上であり，その後血糖の回復を示す.

3）糖尿病者に於ては血糖下降率が 20 分後 $20 \%$ 以下，30分後 $30 \%$ 以下であり，その後も血糖は徐々に低下 し回復傾向は少ない.

4) 副作用として全身僚怠感を 3 名訴えた他，特記すべき副作用はみられなかつた.

以上より本試験は正常人と糖尿病者との鑑別に対して臨床的に使用しうる検査法と考える.

\section{文献}

1) MIRSK et al : Metabolism, $5: 875$, (1956). $\quad$ 2) UNGAR, H. etc $:$ J. Clin. Invest., $37: 627$, (1958). 3) BRIGANTE, J.G. et al : Prensa Med-Argent., $48: 3345,15$, Dec. (1961). 4) CONN, J.W. : Diabetes, $3: 296$, (1954). $\quad$ 5) YALLOW, R.S. : Diabetes, $9: 356$, (1960). 6) WEST, K.M. : Diabetes, $9: 454,(1960)$ 7) FAJANS, S.S. : Metabolism, $21: 371$, (1961). 8) KAPLAN, N,M. : Arch. Intern. Med., $107: 212$, (1961). 19 ) 桜井 : 東京医学誌, $69: 242$. (1961). 